\title{
Upcoming International Conferences
}

\section{BRAZIL}

Brazilian Political Science Association (ABCP): 8th Congress of Brazilian Political Science Association

"Expanding Frontiers of Political Science: Contemporary Challenges to Democracy and Development"

August 1-4 2012

Gramado RS Brazil

www. abcp2012.sinteseeventos.com.br

\section{FRANCE}

CERVEPAS/CREW, Sorbonne Nouvelle University of Paris: The Health and Wealth of US Capitalism: A Critical Condition?

Centre IMAGER, Université Paris-Est Créteil: Extraterritoriality of languages, literatures and civilizations

Centre IMAGER, Université Paris-Est

\section{Créteil}

"Extraterritoriality of Languages, Literatures, and Civilizations: Assessments and Prospects"

October 18, 2012-October 20, 2012

Créteil, France

http://imager.u-pec.fr/actualites/ appels-a-communications/colloqueinternational-l-extraterritorialitedes-langues-litteratures-et-civilisations-bilans-et-perspectives--45766o. kjsp?RH=IMAGER-FR

\section{GERMANY}

German Research Institute for Public Administration Speyer (GRIP) and the School of Public and Environmental Affairs (SPEA) of Indiana University.: Converging and Conflicting Trends in the Public Administration of the US, Europe, and Germany

July 19-20, 2012

Speyer, Germany

http://www.foev-speyer.de/spea
Universities of Mannheim and Heidelberg: Political Economy of International Organizations (PEIO)

February 7-9, 2013

Proposals due September 30, 2012

\section{MEXICO}

Universities of Poitiers (MIMMOC), Caen (ERIBIA), Paris Ouest Nanterre (CREA) and the University of Maine (3L. AM) Le Mans.: Who Governs in the Americas and in Europe?

November 15-17, 2012

Mexico City, Mexico

http://mimmoc.labo.univ-poitiers.fr/spip. php?article93\&lang=en

\section{NETHERLANDS}

Belgian and Dutch Political Science Associations: 11th Dutch-Belgian Political Science Conference EGPA/ASPA/Radboud University Nijmegen/University of Baltimore: 8th TAD (Transatlantic Dialogue) on Transitions in Governance

Interpretive Policy Analysis

\section{NEW ZEALAND}

New Zealand Contemporary China Research Centre, Victoria University of Wellington; and School of Government, Peking University: The Chinese Model of Modern Economic Development and Social Transformation: Theory and Debate

August 13-14, 2012

Wellington, New Zealand http: www.victoria.ac.nz/chinaresearchcentre/

\section{POLAND}

Central and East European International Studies Association (CEEISA): 9th Convention of the Central and East European International Studies Association (CEEISA) - "Boundaries in/of international relations"

September 20-22, 2012

Krakow, Poland

http: ceeisa.org

\section{SOUTH AFRICA}

University of Witwatersrand (Wits): Old Land New Practices

September 11-14, 2012

Grahmstown, Eastern Cape Province, South Africa

http://www.oldlandnewpractices.co.za

\section{UNITED KINGDOM}

ISME: Annual Conference, International Society for MacIntyrean Enquiry

July 19-21, 2012

Tony.burns@nottingham.ac.uk; Kelvin.

knight@londonmet.ac.au

Elections, Public Opinion and Parties specialist group of the Political Studies Association of the UK: Elections, Public Opinion and Parties (EPOP) Conference 2012 September 7-9, 2012

Oxford, UK

http://www.sociology.ox.ac.uk.epop2012

Visit APSA's website for listings of conferences, seminars, and programs in the profession at https://apsanet.org/conferences.cfm 